удК 343.985

\title{
В. В. Тіщзенко
}

\section{РОЗКРИТТЯ ЗЛОЧИНіВ ЯК ПІЗНАВАЛЬНА ДіЯЛЬНіСТЬ і ОСНОВНЕ ЗАВДАННЯ РОЗСЛ ІДУВАННЯ}

У новому Кримінальному процесуальному кодексі України (2012р.), на відміну від раніше чинного ҚПК України (1960р.), у ст. 2 КПК, присвяченій завданням кримінального провадження, відсутня вказівка на необхідність розкриття злочинів. У завданнях кримінального провадження тепер говориться не про швидке і повне розкриття злочинів, а про забезпечення швидкого, повного і неупередженого розслідування і судового розгляду. Певно, законодавця не задовольняв термін «розкриття», і він його замінив на більш відповідний ідеї і завданням нового ҚПК термін «розслідування і судовий розгляд». Але чи означає це, що термін «розкриття злочину» повинен зникнути з наукових досліджень, з аналізу та оцінки слідчої та судової практики?

Свого часу тлумачення поняття «розкриття злочинів» викликало чимало дискусій. Пояснювалося це, перш за все, тим, що кримінальнопроцесуальний закон хоча і містив вказаний термін, але не визначав його поняття. Звідси - неоднозначне трактування його змісту, можливості повного і неповного розкриття злочинів, процесуального моменту, з яким пов'язувався факт розкриття злочину та ін.

Потрібно сказати, що у кримінальному процесі, у криміналістиці, у теорії і практиці оперативно-розшукової діяльності термін «розкриття злочинів» розумівся по-різному, виходячи з функцій і завдань розглянутих видів діяльності, законів, підзаконних актів, відомчих вказівок, інструкцій та роз'яснень, пов'язаних з діяльністю відповідних правоохоронних органів.

Так, у кримінальному процесі «розкриття» означало позитивний результат розслідування злочину, внаслідок чого відбувається встановлення всіх обставин, що підлягають доказуванню, і винної особи. Момент розкриття злочину при цьому позв'язувався або з пред'явленням обвинувачення [1], або з закінченням досудового розслідування і складанням 
обвинувального висновку [2]. Пріоритетною все ж була думка, що розкритим вважається злочин, щодо якого було закінчено кримінальне провадження і по справі прийнято і набуло законної сили одне з судових рішень з нереабілітуючих підстав (обвинувальний вирок та ін.). Якщо ж судове рішення містило виправдувальний вирок або вказівку на припинення кримінальної справи за реабілітуючими підставами (відсутністю події або складу злочину, недоведеністю участі обвинуваченого у вчиненні злочину), говорити про розкриття злочину не було підстави [3]. Нерозкритим вважався і злочин, факт якого в ході розслідування був доведений, але особа, яка його вчинила, залишилася не встановленою. У цьому випадку розслідування такого злочину припинялося, але обов'язок зі встановлення винної особи слідчими, а також за допомогою оперативно-розшукових заходів залишалася (ст. 209 КПК України 1960 р.).

У теорії оперативно-розшукової діяльності термін «розкриття злочину» трактувався, найчастіше, інакше. Злочин вважали розкритим з моменту встановлення факту здійснення злочину і виявлення особи підозрюваного [4; 5]. В такому сенсі розкриття злочину могло стосуватися лише злочинів, вчинених в умовах неочевидності.

У криміналістиці одні автори погоджувалися з розумінням розкриття злочину, яке висловлювалося у кримінальному процесі [6], інші автори схилялися до його розуміння в теорії ОРД [7]. Відзначалися і спроби створення криміналістичного поняття розкриття злочинів. Цікавою, хоча й дискусійною $є$ думка В.Г. Танасевича про те, що в криміналістичному сенсі розкриття злочинів на досудовому слідстві носить попередній характер, оскільки грунтується тільки на оцінці досягнутого результату слідчим, а остаточно рішення про розкриття злочину приймається судом. Крім того, в криміналістичному аспекті розкриття включає і виявлення злочину, а також викриття винних осіб [8]. Таким чином, виходить, що поняття розкриття ширше процесуального, тобто останнім не включається процес виявлення злочину [9], а викриття винних розглядалося в ст. 2 КПК України 1960 р. як завдання, що виходить за межі розкриття злочину, оскільки називається поряд з ним.

На відміну від думки В. Г. Танасевича, точка зору Р. С. Бєлкіна полягає в тому, що криміналістичне поняття розкриття злочинів включає в себе діяльність з розслідування злочинів, спрямовану на отримання інформації, що дає підставу до висунення версії про вчинення злочину певною особою [10]. 3 таким вузьким розумінням розкриття злочину не можна погодитися, оскільки поява фігури підозрюваного ще не означає точного встановлення винної особи та інших обставин злочину.

А. А. Чебуренков вважає, що розкриття злочину можна розглядати як частину загального процесу розслідування, спрямовану на отримання інформації, необхідної і достатньої для висновку про те, чи мала місце подія злочину і хто його вчинив, а процесуальним моментом його досягнення слід вважати винесення слідчим постанови про притягнення особи як обвинуваченого [11]. Таким чином, його думка збігається з зазна- 
ченими поглядами деяких представників процесуальної та криміналістичної науки.

Л. Д. Самигін розглядає розкриття злочинів як головну задачу початкового етапу розслідування, пов'язуючи їі рішення з встановленням події злочину і винних осіб, оскільки в іншому випадку розслідування не може перейти в наступний, основний етап і припиняється або призупиняється [12]. Навряд чи можна погодитися, що розкриття злочину в повному обсязі - завдання тільки початкового етапу розслідування. Якщо на початковому етапі завдання з розкриття злочину не було в силу тих чи інших причин виконане, то воно не скасовується, а переноситься на подальший етап розслідування.

Потрібно відзначити, що розкриття злочинів у криміналістиці розглядалося не тільки як практична діяльність, але і як специфічний розумовий процес, своєрідна інтелектуальна технологія, зміст якої займає особливе місце в структурі діяльності з розслідування кримінально-релевантних подій. У практичному аспекті така технологія грунтується на наукових принципах методики розслідування, на криміналістичному аналізі вихідної інформації та слідчої ситуації, оцінці можливості розкриття злочину по «гарячих слідах», вимагає негайної розробки програми початкового етапу розслідування. У теоретичному аспекті вона повинна грунтуватися на наукових принципах криміналістичної методики розслідування, можливості використання тактичних комплексів, технікокриміналістичних засобів, спеціальних знань, ефективної взаємодії служб і підрозділів правоохоронних органів. У цьому зв'язку висловлювалися і обгрунтовувалися навіть пропозиції про створення теорії розкриття злочину $[13 ; 14]$. Однак, незважаючи на певну привабливість такої ідеї, вона навряд чи може бути реалізована, тому що зміст запропонованої теорії виявився занадто громіздким, не має чітких меж і по суті охоплював всі основні теоретичні положення криміналістики, і тому не набув широкої підтримки [15].

Викликали питання і вживання в назві та змісті теоретичних робіт, практичних посібників, керівництв і вказівок вираз «розкриття і розслідування злочинів», що передбачало різний зміст цих понять, якесь їх протиставлення чи, в усякому випадку, певне доповнення. Якщо йдеться про розкриття злочину як ціль, а про розслідування як процесуальну форму і зміст слідчої діяльності, то хіба недостатньо було б говорити тільки про розслідування, припускаючи наявність у ньому діяльності слідчого, спрямовану на розкриття злочинів? Якщо ж в обох випадках маються на увазі не співпадаючі за змістом, завданням або методам процеси, форми діяльності, то виникало питання про сутність їх відмінності.

Необхідно зауважити, що розуміння розкриття злочину як специфічної діяльності цілком виправдано, тому що крім процесуальної форми і засобів, що забезпечують досягнення завдань кримінального провадження, вона включає в себе використання методів, прийомів, засобів і тех- 
нологій, що знаходяться у площині інформаційно-пізнавальної, операційно-пошукової діяльності. У цьому аспекті по успішно проведеному розслідуванню злочину можна аналізувати, як, якими методами і засобами воно було здійснено, тобто розкрито, кладучи досвід такої діяльності в загальну скарбничку криміналістичних знань з методики і тактики розслідування відповідних категорій злочинів.

Їноді ставиться питання: а чи в усіх випадках розслідування злочинів можна і потрібно говорити про їх розкриття, адже $\epsilon$ злочини, які «очевидні», вихідні дані щодо певного злочину прямо вказують на винну особу, тому доказова інформація начебто лежить на поверхні, потрібно лише акуратно, процесуально правильно зібрати і зафіксувати їі в матеріалах кримінального провадження. Такі злочини не потрібно розкривати, їх потрібно тільки розслідувати [10; 16]. 3 цим не можна погодитися, оскільки зовні «очевидна» подія при більш глибокому його розгляді виявляється не настільки однозначною і простою, як це уявляється з початку розслідування. Причини, механізм і обстановка злочину, мотиви і цілі злочинця, коло причетних до розслідуваної події осіб, їх роль, винність та інші обставини мають бути виявлені, з'ясовані і доведені, а це передбачає здійснення діяльності з розкриття злочину. Власне, лінгвістичне тлумачення терміну «розкриття» означає виявлення, пояснення якої-небудь події неясного змісту [17].

Таким чином, можна констатувати, що в новому КПК України законодавець не використовує термін «розкриття злочину». Можна припустити, що розкриття злочинів не включено в перелік завдань кримінального провадження виходячи з того, мабуть, що розслідування - поняття більш широке. Крім того, не всяка розслідувана подія є злочином, а отже підлягає розкриттю. Можливо, законодавець вирішив уникнути тієї спірності і невизначеності, що пов'язана з неоднозначним розумінням того, в яких випадках і коли злочин слід вважати розкритим. Щоправда, в одному випадку у главі 21 КПК, яка передбачає порядок провадження негласних слідчих (розшукових) дій, у назві ст. 272 йдеться про виконання спеціального завдання з розкриття злочинної діяльності організованої групи або злочинної організації. Однак, судячи зі змісту даної статті, тут мова йде про отримання відомостей, речей і документів слідчим від особи, що виконує спеціальне завдання, завдяки яким стає можливим припинення злочинної діяльності, запобігання нових злочинів, а в кінцевому підсумку - викриття іiі учасників. Думається, що така діяльність вказаної особи створює передумови для розкриття злочинної діяльності певного угруповання, але не становить власне розкриття, та ще й здійснене окремою особою, яка виконує спеціальне завдання.

$\mathrm{У}$ законі також йдеться про єдине кримінальне провадження, що об'єднує досудове розслідування і судовий розгляд, пред’являючи до нього такі вимоги, як швидкість, повнота та неупередженість, які повинні забезпечити залучення кожного винного до відповідальності (ст. 2 КПК України), а також доповнюючи їх принципом законності, який 
передбачає всебічність, повноту та неупередженість дослідження обставин кримінального провадження, дачу їм належної правової оцінки та забезпечення прийняття законних i неупереджених процесуальних рішень (ч. 2 ст. 9 ҚПК України). Втім, швидкість, повнота, всебічність та неупередженість розслідування $€$ його умовами, а не завданнями. У цьому аспекті виділяються інші досить чіткі і певні характеристики стану і досягнутих результатів розслідування: вручення особі повідомлення про підозру (ст. 278 ҚПК України), призупинення досудового розслідування (ст. 280 КПК України), закінчення досудового розслідування (ст.ст. 283-284 КПК України). Але якщо такі формальні ознаки, що вказують на стан кримінального провадження, і можуть задовольнити теорію і практику кримінального процесу, то вони не відображають оцінку результатів слідчої діяльності, якість і проблеми розслідування. На жаль, автори трьох виданих коментарів до нового ҚПК України обходять мовчанням факт зникнення з переліку завдань кримінального провадження завдання з розкриття злочинів [18-20]. Разом з тим в літературі висловлюється думка про доцільність введення такого поняття в норми процесуального закону [21;22].

Що стосується криміналістики, то в їі теоретичних і науково-прикладних дослідженнях не тільки допустимо, але й доцільно використовувати поняття розкриття злочинів, що включає в себе характеристику інформаційно-пізнавальних і технологічних процесів, методів і засобів їх реалізації в ході розслідування з метою встановлення всіх обставин кримінального правопорушення та причетних до нього осіб. У цьому сенсі процес розкриття злочину не $€$ щось відокремлене від розслідування або доповнює його, а розглядається як його інформаційно-пізнавальний, технологічний аспект, який виділяє комплекс криміналістичних операцій, методів, прийомів і засобів для послідовного, поетапного вирішення стратегічних і тактичних завдань досудового розслідування злочинів. Звичайно, успішно здійснюваний процес розслідування невіддільний від його мети, тому повне розкриття злочину потрібно розуміти і як результат встановлення винної особи, а також всіх обставин події, що підлягають доказуванню у відповідність до ст. 91 КПК України і є підставою для закінчення досудового слідства [23]. Дискусійним залишається твердження про вузьке значення поняття розкриття злочинів, пов'язаних з отриманням інформації про вчинення розслідуваного злочину певною особою «в ситуації, коли всі контрверсії перевірені і спростовані» [24]. Потрібно пам'ятати, що процес розкриття злочину являє собою не тільки ланцюжок логічних умовиводів, але і процесуальну діяльність по збиранню, дослідженню та використанню доказів. Тому не можна вважати злочин розкритим (навіть у криміналістичному або оперативно-розшуковому значенні), коли тільки виявляється запідозрена у вчиненні злочину особа, але не доведена іiі винність, не відомі інші суттєві обставини розслідуваної події. Уявляється, що розуміння розкриття злочину як основного завдання роз- 
слідування в наукових дослідженнях і правозастосовчій практиці має бути однаковим.

Хотілося б звернути увагу і на те, що з поняттям розкриття злочину як результату розслідування пов'язане і поняття розкривання злочинів, яке характеризує якісні параметри розслідування з урахуванням специфіки тих чи інших категорій злочинів, регіону, в якому вони відбуваються, місця, часу та інших умов, професійних якостей слідчого та оперативних підрозділів. Здається, що така оцінка роботи слідчих та інших правоохоронних органів повинна існувати і орієнтувати як практиків, так і науковців на відповідні проблеми в боротьбі зі злочинністю.

Таким чином, уявляється, що поняття розкриття злочину доцільно зберегти в наукових дослідженнях у галузі кримінального процесу, криміналістики та теорії оперативно-розшукової діяльності, використовувати його для характеристики результатів розслідування, методів і засобів пошуково-пізнавальної діяльності з виявлення події злочину, встановлення і викриття винних осіб, а також інших обставин події, що входять до предмету доказування.

\section{Л і те ратура і прим і тки}

1. Ефимичев П. С. Расследование преступлений : теория, практика, обеспечение прав личности / П. С. Ефимичев, С. П. Ефимичев. - М. : Юстицинформ, 2009. - С. 38.

2. Майоров Н. Учет раскрытия преступлений / H. Майоров // Социалистическая законность. - 1970. - № 2. - С. 44.

3. Кримінально-процесуальний кодекс України: наук.практ. комент. / за ред. Ю. П. Аленіна. - Х. : Одіссей, 2011. - С. 14-15.

4. Дидоренко Э.А. Основы оперативно-розыскной деятельности в Украине (понятие, принципы, правовое обеспечение) / Э.А. Дидоренко, Б. И. Бараненко, В. Ф. Глазков [и др.]. - К. : Центр учеб. лит., 2007. - С. 29.

5. Робозеров В. Ф. Раскрытие преступлений, совершенных в условиях неочевидности / В. Ф. Робозеров. - Л., 1990. - С. 10.

6. Туполов С. И. Деятельность следственных органов внутренних дел по раскрытию преступлений / С. И. Туполов, Л. Д. Гаухман [и др.]. - М., 1974 - С. 3.

7. Калинин Ю.В. О понятии раскрытия преступлений / Ю. В. Калинин // Вопросы криминалистической методологии, тактики и методики расследования. - M., 1973. - C. 35-36.

8. Советская криминалистика: теоретические проблемы / В.Г. Танасевич. - M. : Юрид. лит., 1978. - С. 180.

9. Интересно, что в теории ОРД также высказывается мнение о раскрытии как о более широком понятии, чем расследование. См.: Меживой О.В. Розкриття злочинів та процес розслідування за новим КПК України : порівняльний аспект / О. В. Меживой // Розкриття злочинів за новим Кримінальним процесуальним кодексом України: матеріали наук.-практ. конф. - К. : Нац. акад. внутр. справ, 2012. - С. 118-119.

10. Белкин Р. С. Курс криминалистики / Р. С. Белкин. - М. : Закон и право, 2001. C. 779.

11. Чебуренков А. А. Основы теории расследования / А. А. Чебуренков. - М. : Юрлитинформ, 2010. - С. 149.

12. Самыгин Л. Д. Расследование преступлений как система деятельности / Л. Д. Самьгин. - М. : Изд. Моск. ун-та, 1989. - С. 36. 
13. Герасимов И. Ф. Проблемы общей теории раскрытия преступлений / И. Ф. Герасимов // Актуальные проблемы советской криминалистики. - М., 1980. - С. 28-31.

14. Гавло В. К. О предмете криминалистики и сфере приложения ее научного потенциала / В.К. Гавло // Актуальные проблемы уголовного процесса и криминалистики на современном этапе. - О., 1993. - С. 112-113.

15. Белкин Р. С. Криминалистика: проблемы сегодняшнего дня / P. С. Белкин. - М. : Норма, 2001. - С. 226-228.

16. Бердичевский Ф. Ю. О предмете и понятийном аппарате криминалистики / Ф. Ю. Бердичевский // Вопросы борьбы с преступностью. - М., 1976. - Вып. 24. - C. $131-149$.

17. Современный толковый словарь русского языка / гл. ред. С. А. Кузнецов. - СПб. : Норинт, 2006. - C. 682.

18. Кримінальний процесуальний кодекс України: наук.-прак. комент. / за заг. ред. В. Г. Гончаренка, В. Т. Нора, М. Є. Шумила. - К. : Юстініан, 2012. - С. 17-20.

19. Кримінальний процесуальний кодекс України : наук.-практ. комент. У 2 т. Т. 1 / за заг. ред. В. Я. Тація, В. П. Пшонки, А. В. Портнова. - Х. : Право, 2012. - С. 6-8.

20. Кримінальний процесуальний кодекс України : наук.-практ. комент. / відп. ред.: С. В. Ківалов, С. М. Міщенко, В. Ю. Захарченко. - Х. : Одіссей, 2013. - С. 16-22.

21. Меживой В. П. Чи має право на існування поняття «Розкриття злочинів»у новому Кримінальному процесуальному кодексі України? / В. П. Меживой // Розкриття злочинів за новим Кримінальним законодавством України : матеріали наук.-практ. конф.. - К. : Нац. акад. внутр. справ, 2012. - С. 74-76.

22. Рожнова В. В. Сучасна концепція кримінального процесу та ï відображення у системі завдань кримінального провадження / B. B. Рожнова // Проблеми правознавства та правоохоронної діяльності. - 2012. - № 4. - С. 122-128.

23. Кузьмічов Я. В. Принципи розкриття злочинів : автореф. дис. ... канд. юрид. наук : 12.00 .09 / Я. В. Кузьмічов. - К., 2008. - С. 13.

24. Мухин Г.Н. Криминалистика: современные проблемы, история и методология / Г. Н. Мухин, Д. В. Исютин-Федотков. - М. : Юрлитинформ, 2012. - С. 28.

\section{А н о т а ц і я}

Tіщенко В.В. Розкриття злочинів як пізнавальна діяльність і основне завдання розслідування. - Стаття.

Стаття присвячена розгляду кримінально-процесуального, криміналістичного та оперативно-розшукового аспектів понять розслідування і розкриття злочинів у світлі нового Кримінального процесуального кодексу України. Обгрунтовується доцільність існування і використання поняття «розкриття злочинів» в наукових дослідженнях, слідчій і судовій практиці.

Ключові слова: злочин, розкриття злочину, пізнавальна діяльність, завдання розслідування.

\section{Ан нот а ция}

Тищенко В.В. Раскрытие преступлений как познавательная деятельность и основная задача расследования. - Статья.

Статья посвящена рассмотрению уголовно-процессуального, криминалистического и оперативно-розыскного аспектов понятий расследования и раскрытия преступлений в свете нового Уголовного процессуального кодекса Украины. Обосновывается целесообразность существования и использования понятия «раскрытие преступлений» в научных исследованиях, следственной и судебной практике.

Ключевые слова: преступление, раскрытие преступления, познавательная деятельность, задачи расследования. 


\section{S u m m a r y}

Tishchenko $V$. Detection of crime as a cognitive activity and the main task of the investigation. - Article.

The article is devoted to the criminal procedure, forensic and investigative and operational aspects of the concepts of crime detection and investigation in light of the new Criminal Procedure Code of Ukraine. The expediency existence and use of the concept of «solving crimes» in research, investigative and judicial practice.

Keywords: crime, crime detection, cognitive activity, the task of investigating. 